\title{
Tertib Berlalu Lintas pada Siswa SMP N 1 Ulakan Tapakis Kabupaten Padang Pariaman
}

\author{
Zalya Hanifah, Henni Muchtar, Isnarmi \\ Program Studi Pendidikan Pancasila dan Kewarganegaraan \\ Universitas Negeri Padang \\ Email: zalyahanifah95@gmail.com
}

\begin{abstract}
ABSTRAK
Penelitian ini bertujuan mendeskripsikan bagaimana tertib berlalu lintas pada siswa SMPN 1 Ulakan Tapakis, mengidentifikasi faktor yang mempengaruhi perilaku tertib pada siswa serta mendskripsikan upaya yang dilakukan pihak terkait (sekolah dan kepolisian) dalam meningkatkan perilaku tertib berlalu lintas pada siswa SMPN 1 Ulakan Tapakis. Jenis penelitian ini adalah penelitian fenomenologi pendekatan kualitatif. Penentuan informan menggunakan teknik purposive sampling. Jenis data adalah data primer dan skunder yang dikumpulkan dengan observasi, wawancara, angket dan studi dokumentasi. Uji keabsahan data melalui teknik triangulasi sumber. Sedangkan teknik analisis data menggunakan teknik reduksi data, penyajian data dan verifikasi data. Hasil penelitian menunjukan siswa belum tertib berlalu lintas, dilahat dari aspek kelengkapan surat kendaraan, aspek perlengkapan kendaraan bermotor, aspek peraturan keselamatan berkendara. Faktor yang mempengaruhi pendidikan, kepribadian, penegak hukum, sarana atau fasilitas. Upaya yang dilakukan meningkatkan perilaku tertib berlalu lintas yaitu penyuluhan. Dari hasil penelitian dapat disimpulkan bahwa 1) siswa belum memahami serta melaksanakan Undang-Undang No. 22 Tahun 2009 tentang Lalu Lintas dan Angkutan Jalan terkait peraturan mengendarai sepeda motor. 2) Siswa memiliki pengetahuan yang baik namun belum diikuti dengan pemahaman yang baik tentang aturan lalu lintas sehingga mempengaruhi sikap dan perilaku, penegak hukum belum melaksanakan tugasnya secara efektif, sarana atau fasilitas lalu lintas belum memadai. 3) Pihak sekolah dan kepolisisan belum maksimal dalam upaya meningkatkan perilaku tertib berlalu lintas pada siswa.
\end{abstract}

\section{Kata Kunci : Perilaku, Tertib, Lalu lintas}

\section{ABSTRACT}

The purposes of this research are to describe the ways of students' traffic order for Junior High School 1 Ulakan Tapakis, identify factors that influence the orderly behavior of the students, and describe the efforts have done by related parties (school and police) in improving the orderly behavior of traffic toward students at Junior High School 1 Ulakan Tapakis.The type of this research is phenomenological research with a qualitative approach. Purposive sampling technique is used to determine informants. The types of data are primary and secondary data which are collected through observation, interviews, questionnaire, and documentation studies. The test of data validity is done through triangulation technique. While the data analysis techniques used data reduction techniques, data presentation, and data verification. The results of the research showed that the students have not yet orderly traffic. It can be seen from the aspect of completeness of the vehicle letter, in the aspect of Motor Vehicle 
Tertib Berlalu lintas..

Equipment, in the aspect of Safety Rules Driving. Factors that affect education, personality, law enforcement, means or facilities. Efforts are made to improve the behavior of orderly traffic that is counseling. From the results of the study can be concluded that 1) Students do not understand and implement Law no. 22 of 2009 on Traffic and Road Transport related to motorcycle riding regulations. 2) Students have good knowledge but it is not followed by a good understanding of traffic rules so that influence attitudes and behavior, law enforcers have not carried out their duties effectively, means or facilities of traffic is not adequate. 3) The school and the police have not been maximized in an effort to improve the behavior of traffic order to students.

Keywords: Behavior, Orderly, Traffic

\section{PENDAHULUAN}

Menurut Poerwadarminta (2003:780) ketertiban berasal dari kata tertib yang berarti aturan, peraturan yang baik. Ketertiban merupakan aturan peraturan, kesopanan, peri kelakuan yang baik dalam pergaulan, keadaan serba teratur baik. Dalam kamus Besar Bahasa Indonesia tertib berarti teratur menurut aturan, rapi, sedangkan ketertiban merupakan peraturan (dalam masyarakat dan sebagainya) atau keadaan serba teratur baik.

Lalu Lintas di dalam UndangUndang Republik Indonesia No.22 Tahun 2002 Tentang Lalu Lintas dan Angkutan Jalan didefenisikan sebagai gerak kendaraan dan orang di ruang lalu lintas jalan. Ruang lalu lintas jalan adalah prasarana yang diperuntukan bagi gerak pindah kendaraan, orang atau barang yang berupa jalan dan fasilitas pendukung. Menurut Warpani Suwardjoko (2002:1) lalu lintas adalah kegiatan lalu lalang atau gerak kendaraan, orang atau hewan di jalan.

Tertib berlalu lintas dapat didefenisikan sebagai sikap atau perilaku yang taat terhadap aturan dalam melakukan kegiatan lalu lintas di jalan raya. Menurut Undang-Undang No.22 Tahun 2009 Pasal 105 menjelaskan bahwa setiap orang yang menggunakan jalan wajib:

a. berperilaku tertib dan/atau

b. mencegah hal-hal yang dapat merintangi, membahayakan keamanan dan keselamatan lalu lintas dan angkutan jalan, atau yang dapat menimbulkan kerusakan jalan.

Kehidupan yang tertib harus diciptakan dalam berbagai lingkungan kehidupan salah satunya dijalan raya. Kurangnya sarana dan prasarana transportasi umum menyebabkan tingginya angka kepemilikan kendaraan bermotor pribadi. Tingginya angka penggunaan kendaran bermotor saat ini tidak diimbangi dengan perilaku tertib dalam berlalu lintas hal tersebut terlihat dari tingginya angka pelanggaran lalu lintas yang terjadi sehingga menimbulkan kecelakaan lalu lintas.

Hal tersebut sesuai dengan data yang diperoleh dari Korps Lalu Lintas Kepolisisan Negara Indonesia (2016) bahwa setiap tahunnya 
jumlah laka lantas yang terjadi terus meningkat. Pada periode 09/10/2015-06/01/2016 tercatat hampir 25.000 kejadian, jumlah tersebut meningkat pada periode 05/07/2016-02/10/2016 tercatat hampir 30.000 kejadian. Jenis kendaraan yang paling tinggi terlibat kecelakaan pada dua periode tersebut yaitu pengemudi sepeda motor. Dalam kecelakaan lalu lintas pengguna jalan kelompok usia 15-25 tahun adalah kelompok usia yang paling rentan terlibat laka lantas.

Fenomena tersebut juga terlihat di kabupaten padang pariaman dimana rata-rata masyarakat menggunakan sepeda motor dalam aktivitas sehari-hari namun tidak diimbangi dengan perilaku tertib berlalu lintas. Hal tersebut terlihat dari data yang diperoleh dari Satlantas Kabupaten Padang Pariaman (2016) jumlah pelanggaran lalu lintas meningkat setiap tahunnya, pada tahun 2016 tercatat pelanggaran lalu lintas yang terjadi sebanyak 15.333 kasus. Dari pelanggaran lalu lintas yang terjadi pada tahun 2016 jika ditinjau dari segi pendidikan maka pelanggar terbanyak yaitu pelajar SMA, kemudian mahasiswa, pelajar SMP dan terakhir pelajar SD.

Sesuai dengan hasil observasi yang telah penulis lakukan di daerah Ulakan Kecamatan Ulakan Tapakis 2 Juli 2017, terlihat rata-rata masyarakat menggunakan sepeda motor dalam mobilitas mereka melaksanakan aktivitas sehari-hari. Tingginya angka penggunaan kendaraan bermotor di Kecamatan
Ulakan Tapakis salah satunya terlihat dari besarnya jumlah pelajar yang mengendarai sepeda motor ke sekolah. Pelajar yang menggunakan sepeda motor ke sekolah terdiri dari pelajar SMA dan pelajar SMP.

Setiap pengendara kendaraan bermotor harus memiliki Surat Izin Mengemudi Sesuai dengan jenis kendaraanya. Kepemilikian SIM juga harus memenuhi syarat usia minimal yaitu 17 tahun untuk SIM C jenis kendaraan sepeda motor. Untuk siswa SMP dengan rata-rata usia 12-16 tahun tentu belum diperbolehkan mengendarai sepeda motor.

Sesuai dengan observasi yang telah penulis lakukan di SMP N 1 Ulakan Kecamatan Ulakan Tapakis pada tanggal 3 Juli 2017, terlihat bahwa banyak dari siswa SMP N 1 Ulakan yang mengendarai sepeda motor, hal ini juga dibenarkan oleh salah satu pegawai SMP N 1 Ulakan tapakis dimana dari wawancara awal yang penulis lakukan dengan ibu Nurhayati diperoleh keterangan bahwa 35\% dari jumlah keseluruhan siswa SMP N 1 Ulakan Tapakis mengendarai sepeda motor ke sekolah dengan jumlah siswa tahun ajaran 2017-2018 berjumlah 505 siswa.

Dari hasil observasi yang telah penulis lakukan 3 Juli 2017 juga terlihat berbagai pelanggaran lalu lintas yang dilakukan oleh siswa SMPN 1 Ulakan Tapakis yaitu : 
Tabel 1

Distribusi Jenis pelanggaran lalu lintas yang dilakukan siswa SMPN 1 Ulakan Tapakis

\begin{tabular}{|l|l|}
\hline No & \multicolumn{1}{|c|}{ Jenis pelanggaran } \\
\hline 1 & Tidak menggunakan helm \\
\hline 2 & $\begin{array}{l}\text { Tidak menghidupkan lampu } \\
\text { utama }\end{array}$ \\
\hline 3 & Berboncengan tiga \\
\hline 4 & Berkendara tidak stabil \\
\hline 5 & $\begin{array}{l}\text { Tidak Menggunakan knalpot } \\
\text { standar }\end{array}$ \\
\hline 6 & $\begin{array}{l}\text { Sepeda motor tidak } \\
\text { dilengkapi dengan kaca } \\
\text { spion }\end{array}$ \\
\hline
\end{tabular}

Sumber:Dokumen Observasi

Pelanggaran yang dilakukan siswa ini tidak hanya membahayakan pengendara sendiri tetapi juga membahayakan pengguna jalan lainnya serta mengganggu ketertiban umum. Ketertiban merupakan sikap yang harus ditanamkan kepada semua warga Negara agar tercapainya kehidupan yang aman dan damai. Untuk mencapai semua itu perlu adanya upaya untuk menanamkan sikap tertib itu sendiri.

Berdasarkan uraian tersebut menjadi landasan bagi peneliti untuk mengadakan penelitian dengan judul "Tertib Berlalu Lintas Pada Siswa SMPN 1 Ulakan Tapakis Kabupaten Padang Pariaman".

METODE PENELITIAN
Metode penelitian yang peneliti gunakan adalah penelitian fenomenologi dengan pendekatan kualitatif yaitu mendeskripsikan atau menggambarkan tertib berlalu lintas pada siswa SMP N 1 Ulakan Tapakis Kabupaten Padang Pariaman. Penentuan informan menggunakan teknik purposive sampling. Jenis data adalah data primer dan skunder yang dikumpulkan dengan observasi, wawancara, angket dan studi dokumentasi. Uji keabsahan data melalui teknik triangulasi sumber. Sedangkan teknik analisis data menggunakan teknik reduksi data, penyajian data dan verifikasi data.

\section{HASIL DAN PEMBAHASAN}

1. Tertib Berlalu Lintas Pada Siswa SMPN 1 Ulakan Tapakis

\section{a. Kelengkapan \\ Surat Kendaraan \\ Berdasarkan Undang-} Undang Nomor 22 Tahun 2009 Tetang Lalu Lintas dan Angkutan Jalan pasal 77 ayat (1) menjelaskan bahwa "Setiap orang yang mengemudikan kendaraan bermotor di jalan wajib memiliki surat izin mengemudi sesuai dengan jenis kendaraan bermotor yang dikemudikan". Dari hasil penelitian diketahui bahwa tidak ada siswa SMPN 1 Ulakan Tapakis yang memiliki surat izin mengemudi, jadi dapat dikatakan bahwa siswa SMPN 1 Ulakan Tapakis belum tertib berlalu lintas dilihat dari kelengkapan surat kendaraan.

Peraturan tentang wajib membawa STNK termuat dalam 
pasal 106 ayat (5) Undang-Undang No.22 Tahun 2009 Tentang Lalu Litas dan Angkutan Jalan:

Pada saat diadakan pemeriksaan kendaraan bermotor di jalan setiap orang yang mengemudikan kendaraan bermotor wajib menunjukan:

a. Surat Tanda Kendaraan Bermotor atau Surat Tanda Coba Kendaraan Bermotor

b. Surat Izin Mengemudi

c. Bukti Lulus Uji Berkala dan/atau

d. Tanda bukti lain yang sah.

Dari hasil temuan penelitian diketahui bahwa siswa SMPN 1 Ulakan Tapakis yang membawa STNK saat berkendara ke sekolah lebih sedikit dari pada siswa yang membawa STNK saat berkendara ke sekolah. Jadi dapat disimpulkan siswa SMPN 1 Ulakan Tapakis belum tertib berlalu lintas dari aspek kelengkapan surat kendaraan.

\section{b. Perlengkapan Kendaraan Bermotor Berdasarkan Undang-} Undang Republik Indonesia Nomor 22 Tahun 2009 Tentang Lalu Lintas dan Angkutan Jalan dari pasal 57 ayat (1), 57 ayat (2), 48 ayat (1), 48 ayat (2), 48 ayat (3), 106 ayat (3) (terlampir) dapat disimpulkan bagi kendaraan bermotor wajib memenuhi perlengkapan kendaraan berupa helm standar nasional indonesia bagi sepeda motor serta memenuhi persyaratan teknis dan layak jalan yang meliputi kaca spion, klakson, lampu utama, lampu rem, lampu penunjuk arah, alat pemantul cahaya, alat pengukur kecepatan, knalpot dan kedalam alur ban.

Dari hasil temuan penelitian diketahui bahwa masih banyak siswa SMPN 1 Ulakan Tapakis yang sepeda motornya tidak dilengkapi perlengkapan kendaraan barmotor sebagaimana yang diatur dalam Undang-Undang Lalu Lintas dan Angkutan Jalan. Hal ini terlihat dari adanya sepeda motor siswa yang tidak dilengkapi dengan kaca spion, lampu utama, lampu penunjuk arah, serta lampu rem. Selain itu juga terlihat bahwa tidak ada siswa SMPN 1 Ulakan Tapakis yang menggunakan helm saat berkendara ke sekolah. Jadi dapat disimpulkan bahwa siswa SMPN 1 Ulakan Tapakis belum sepenuhnya tertib berlalu lintas dilihat dari aspek perlengkapan kendaraan bermotor, hal tersebut terbukti dari masih banyaknya siswa yang tidak memenuhi perlengkapan kendaraan bermotor sesuai aturan UndangUndang.

\section{c. Peraturan Keselamatan Berkendara}

Keselamatan merupakan hal utama yang harus diperhatikan oleh pengendara dalam mengendarai kendaraan bermotor, hal tersebut diatur dalam beberapa pasal diantaranya yaitu pasal 106 ayat (1), 106 ayat (8), 106 ayat (9), 107 ayat (2), 57 ayat (2) UU No.22 Tahun 2009. Dari pasal-pasal tersebut dapat disimpulkan bahwa untuk mewujudkan keamanan dan keselamatan berlalu lintas bagi pengguna sepeda motor yaitu harus berkonsentrasi dalam berkendara, 
pengemudi

menggunakan

diwajibkan helm SNI, menghidupkan lampu utama di siang hari, serta dilarang membawa penumpang lebih dari satu orang.

Dari hasil temuan penelitian terlihat bahawa terdapat siswa yang melihat handphone saat berkendara, berkendara beriringan, tidak ada siswa yang menggunakan helm saat berkendara ke sekolah, terlihat adanya siswa yang tidak menghidupkan lampu utama, serta adanya siswa yang berboncengan tiga saat mengendarai sepeda motor. Jadi dapat disimpulkan siswa SMPN 1 Ulakan Tapakis belum sepenuhnya tertib berlalu lintas dilihat dari aspek peraturan keselamatan berkendara, hal tersebut terbukti dari masih banyak siswa yang mengabaikan keselamatan saat mengendarai sepeda motor.

\section{Faktor Pendorong Sikap Tertib Berlalu Lintas Pada Siswa SMPN 1 Ulakan Tapakis}

a. Faktor Internal

1) Faktor Pendidikan

Menurut Sadono Soni (2017:8) perilaku tertib seseorang dipengaruhi oleh pendidikan sesorang itu, begitu pula dengan perilaku tertib dalam berlalu lintas sedikit banyaknya di pengaruhi oleh pengetahuan seseorang terhadap aturan berlalu lintas itu sendiri. Perilaku tertib juga dipengaruhi oleh kesadaran seseorang terhadap hukum atau aturan. Senada dengan penjelasan diatas, Soekanto Soerjono (1990:34) menjelaskan bahwa pengetahuan dan pemahaman seseorang mengenai hukum mempengaruhi kepatuhan seseorang terhadap hukum tersebut yang nantinya akan diwujudkan melalui sikap dan perilaku dalam kehidupan sehari-hari.

Dari hasil penelitian yang peneliti temukan di lapangan diketahui bahwa siswa SMPN 1 Ulakan Tapakis telah memiliki pengetahuan tentang tata tertib dalam berlalu lintas. Hal tersebut diketahui dari hasil wawancara peniliti bersama beberapa siswa dan juga di perkuat oleh pernyataan guru SMPN 1 Ulakan Tapakis sendiri.

Pemahaman terhadap hukum adalah sejumlah informasi yang diperoleh seseorang mengenai isi peraturan dari suatu hukum tertentu. Seseorang tidak semestinya jarus terlebih dahulu mengetahui adanya suatu aturan tertulis yang mengatur suatu hal. Akan tetapi yang dilihat disini adalah bagaimana persepsi mereka mengahadapi berbagai hal, dalam kaitannya dengan norma-norma yang ada dalam masyarakat. Persepsi ini biasanya diwujudkan melalui sikap mereka terhadap tingkah laku sehari-hari.

Dari hasil temuan yang peneliti peroleh di lapangan diketahui bahwa pemahaman siswa SMPN 1 Ulakan Tapakis tentang tata tertib berlalu lintas dapat dikatakan masih kurang, hal tersebut terbukti dengan masih banyaknya siswa yang belum tertib dalam berlalu lintas serta masih banyaknya pelanggaran yang terlihat yang 
dilakukan oleh siswa. hal tersebut terbukti dari hasil angket serta hasil wawancara yang peneliti lakukan dengan beberapa guru dan juga dari pengamatan observasi yang telah peneliti lakukan.

\section{2) Faktor Kepribadian}

Sikap seseorang terhadap hukum akan mempengaruhi perilaku mereka dalam kehidupan sehari-hari. Sikap terhadap hukum adalah kecendrungan untuk menerima hukum karena adanya penghargaan terhadap hukum sebagai suatu yang bermanfaat atau menguntungkan jika huku ditaati. perilaku hukum merupakan hal yang utama dalam kesadaran hukum, karena disini dapat dilihat apakah suatu peraturan berlaku atau tidak dalam masyarkat (Soekanto, Sorjono 1990:34).

Dari hasil temuan yang peneliti temukan dilapangan diketahui bahwa sikap siswa terhadap aturan-aturan berlalu lintas belum sepenuhnya menerima terlihat dari masih banyaknya siswa yang melakukan berbagai pelanggaran lalu lintas. Siswa SMPN 1 Ulakan Tapakis belum sepenuhnya berperilaku sesuai aturan dalam hal berlalu lintas. Hal tersebut terlihat dari masih terdapatnya siswa yang melakukan berbagai pelanggaran lalu lintas.

\section{b. Faktor Eksternal}

1) Undang-Undang

Menurut Soekanto Soerjono (2007:11) undang-undang dalam arti materil adalah peraturan tertulis yang berlaku umum dan dibuat oleh penguasa pusat dan daerah yang sah. Undang-undang memberikan sanksi yang tegas kepada pelanggarnya sehingga diharapkan mampu memberikan efek jera kepada setiap pelanggarnya. Begitu juga dengan halnya Undang-undang yang mengatur tentang berlalu lintas sangat mempengaruhi ketertiban pengguna jalan.

Dari hasil temuan yang peneliti temukan dilapangan ditemukan bahwa Undang-Undang Lalu Lintas Mempengaruhi ketertiban siswa SMPN 1 Ulakan Tapakis dalam berlalu lintas karena siswa merasa takut dengan sanksisanksi yang diberikan jika melakukan pelanggaran.

2) Penegak Hukum

Menurut Soekanto Sorjono (2011:19) faktor penegak hukum memiliki peranan yang sangat penting dalam fungsinya hukum. Menurut Puji Wulandari Kuncorowati (2009:13) menyatakan aparat penegak hukum merupakan panutan bagi masyarakat dalam memberikan kesadaran hukum pada masyarakat dan mengayomi masyarakat. Menurut Soekanto Soerjono dan Mustafa Abdullah (1987:15) jika peraturan sudah baik akan tetapi kualitas petugas kurang baik, maka aka nada masalah. Demikian pula apabila peraturannya buruk, sedang kualitas petugasnya baik, akan mungkin juga timbul masalah-masalah.

Dari hasil penelitian yang telah dilakukan diketahui bahwa faktor penegak hukum sangat 
mempengaruhi ketertiban siswa dalam berlalu lintas serta dapat disimpulkan pihak kepolisian belum melaksanakan tugasnya dengan baik dalam hal penegakan hukum berlalu lintas di kecamatan Ulakan Tapakis.

3) Fasilitas atau Sarana

Soekanto Soerjono (2007:37) mengatakan tanpa adanya sarana atau fasilitas maka tidak mungkin penegakan hukum akan berlangsung dengan lancar fasilitas merupakan sarana pendukung bagi terciptanya kepatuhan masyarakat. Fasilitas sebagai saran untuk mencapai tujuan. Ruang lingkupnya adalah sarana fisik sebagai faktor pendukung. Faktor pendukung yang dimaksud adalah rambu-rambu lalu lintas, sarana mobilitas, sarana komunikasi, jalan dan kelengkapan perorangan.

Dari hasil penelitian yang telah dilakukan di lapangan diketahui bahwa fasilitas atau sarana lalu lintas di kecamatan Ulakan Tapakis masih belum lengkap, seperti tidak tersedianya lampu lalu lintas, tidak adanya sarana atau transportasi umum. Namun untuk rambu-rambu lalu lintas sudah mulai dilengkapi oleh dinas perhubungan serta untuk struktur jalan di kecamatan ulakan tapakis sudah bagus walaupun masih ada kerusakan jalan di beberapa tempat.

\section{Upaya Pihak Terkait (Sekolah Dan Kepolisian) Dalam Meningkatkan Sikap Tertib 1 Ulakan Tapakis Berlalu Lintas Pada Siswa SMPN}
a. Pihak Sekolah

Menurut Puji Wulandari Kuncorowati (2009:5) sekolah dapat melakukan upaya untuk meningkatkan kesadaran hukum lalu lintas siswa terutama dalam mengemudikan sepeda motor. Tindakan penyadaran hukum pada siswa oleh sekolah dapat dilakukan dengan memberikan pengetahuan dan pemahaman. Sekolah merupakan lembaga formal yang memberikan pendidikan kepada peserta didiknya terutama memberikan pengetahuan dan pemahaman terhadap suatu peraturan seperti peraturan tetang lalu lintas dan angkutan jalan. Pendidikan ini dapat dilakukan dengan cara sosialisasi dan penyuluhan-penyuluhan mengenai tata cara berlalu lintas dengan bantuan polisi lalu lintas.

Dari hasil penelitin yang peneliti temukan di lapangan diperoleh hasil bahwa pihak SMPN 1 Ulakan Tapakis telah melakukan upaya dalam meningkatkan sikap tertib berlalu lintas kepada siswa melalui himbauan mengenai tata tertib berlalu lintas, diadakannya larangan bagi siswa membawa motor ke sekolah, serta bekerja sama dengan pihak kepolisisan dalam melakukan penyuluhan mengenai hukum berlalu lintas.

\section{b. Pihak Kepolisian}

Polisi mempunyai tugas untuk melaksanakan membina masyarakat untuk meningkatkan kesadaran hukum masyarakat serta kataatan warga masyarakat terhadap hukum dan peraturan perundang-undangan. Kegiatan 
tersebut dapat dilakukan dengan cara memberikan penyuluhan hukum. Menurut Ali Zainuddin (2014:69) bahwa penyuluhan hukum adalah kegiatan untuk meningkatkan keasadaran hukum masyarakat berupa penyampaian dan penjelasan peraturan hukum kepada masyarakat agar setiap masyarakat mengetahui dam memahami apa yang menjadi hak, kewajiban dan wewenangnya sehingga terciptanya sikap dan perilaku berdasarkan hukum, yakni disamping mengetahui, memahami, menghayati sekaligus mematuhi/mentaatinya.

Dari hasil temuan yang peneliti temukan dilapangan diketahui bahwa pihak Satlantas Kabupaten Padang Pariaman telah melakukan berbagai upaya dalam meningkatkan ketertiba siswa dalam berlalu lintas. Pihak kepolisian telah melakukan penyuluhan secara langsung kepada siswa SMPN 1 Ulakan Tapakis dalam kegiatan upacara bendera. Selain itu pihak kepolisian juga telah melakukan pendidikan hukum melalui kegiatan razia, memberikan arahan kepada orang tua siswa yang terjaring razia serta melakukan kerja sama dengan dinas pendidikan untuk melaksanakan kegiatan penyuluhan ke sekolah-sekolah. namun untuk kegiatan penyuluhan tidak langsung belum ada dilakukan pihak kepolisian kabupaten padang pariaman.

\section{KESIMPULAN}

Berdasarkan temuan penelitian dan pembahasan mengenai tertib berlalu lintas pada siswa SMPN 1 Ulakan Tapakis, maka dapat diambil kesimpulan :

1. Siswa SMP N 1 Ulakan Tapakis belum memahami serta melaksanakan UndangUndang No.22 Tahun 2009 tentang Lalu Lintas dan Angkutan Jalan terkait aturan mengendarai sepeda motor.

2. Faktor-faktor yang mempengaruhi kesadaran hukum berlalu lintas pada siswa SMPN 1 Ulakan Tapakis :

a. Faktor Internal, dilihat dari pendidikan diketahui bahwa pengetahuan siswa mengenai tata tertib berlalu lintas sudah cukup baik, namun untuk segi pemahamannya masih kurang. Dilihat dari kepribadian siswa sikap dan pola tingkah laku siswa masih banyak siswa yang tidak menerima dan mematuhi peraturan dalam mengemudikan sepeda motor.

b. Faktor Eksternal, faktor unang-undang yang berlaku terutama peraturan yang mengatur tentang kendaraan bermotor belum bisa diberlakukan secara efektif di daerah Ulakan Tapakis karena di daerah Ulakan Tapakis tidak ada transportasi umum selain itu jarak tempat tinggal siswa juga jauh dengan 
sekolah. penegak hukum belum efektif dalam menegakan peraturan. Sarana dan fasilitas lalu lintas di Ulakan Tapakis belum lengkap.

3. Upaya-upaya yang dilakukan pihak sekolah dan kepolisisan dalam meningkatkan tertib berlalu lintas pada siswa SMPN 1 Ulakan Tapakis:

a. Pihak SMPN 1 Ulakan Tapakis belum maksimal dalam upaya meningkatkan ketertiban berlalu lintas pada siswa

b. Pihak kepolisian belum bisa memberikan efek jera kepada siswa yang ketahuan melakukan pelanggaran dan penyuluhan yang dilakukan pihak kepolisian ini belum dilakukan secara berkesinambungan.

\section{DAFTAR PUSTAKA}

\section{Buku}

Ali, Zainuddin. 2014. Sosiologi Hukum. Jakarta: Sinar Grafika.

Poerwadarminta,W.J.S. 2003. Kamus Umum Bahasa Indonesia. Jakarta: Balai Pustaka Soekanto, Soerjono. 1990. Polisi Dan Lalu Lintas (Analisis Menurut Sosiologi Hukum). Bandung: Mandar Maju.

Soekanto, Soerjono.2007. Sosiologi Suatu Pengantar. Jakarta: Raja Grafindo Persada.

Soekanto, Soerjono. 2011. Faktor-Faktor Yang Mempengaruhi Penegakan Hukum. Jakarta: Raja Grafindo Persada.

Soekanto, Soerjono dan Mustafa Abdullah. 1987. Sosiologi Hukum Dalam Masyarakat. Jakarta: Raja Grafindo Persada

Warpani, Suwardjoko. 2002. Pengelolaan Lalu Lintas dan Angkutan Jalan. Bandung : ITB. Jurnal

Puji, Wulandari Kuncorowati. 2009. Menurunya Tingkat Kesadaran Hukum Masyarakat Di Indonesia. Jurnal Civics. Vol.6, No.1. Juni 2009.

Sadono, Soni. 2017. Budaya Disiplin Berlalu Lintas Kendaraan Roda Dua Di Kota Bandung. Jurnal PKn Progresif. Vol.12. No.1.

Undang-undang

Undang-Undang No.22 Tahun 2009 Tentang Lalu Lintas Dan Angkutan Jalan

Internet

https://www.korlantas-irsms.info/graph/violationTypeData 